\title{
Inventory Evaluation Model and Application of Shipbuilding Enterprise Based on the Method of Optimal Combination
}

\author{
Bing Sun, Hongying Wang \\ School of Economics and Management, Harbin Engineering University \\ wanghongying0723@163.com
}

\begin{abstract}
As there is no scientific norm in China in managing the inventory of manufacturing enterprises in the ship industry, the managers always have more than one inventory evaluation index systems. Based on the theoretical research and field investigation, we construct an inventory evaluation index system consisting of 20 tertiary indicators of ship industry. We adopt the optimal combination method which composes of G1, fuzzy Borda number analytical method, entropy value method and deviation to investigate the case study. We propose that income index, operation index and security index are the most significant indicators to evaluate the inventory of the enterprise. The shipbuilding enterprise of empirical analysis is used to verify the validity of the conclusions.
\end{abstract}

Keywords: optimal combination method, ship industry, inventory evaluation

\section{Introduction}

Globalization, product proliferation, and fast product innovation have significantly increased the complexities of supply chains in many industries [1]. As an important part of enterprise's production and management, inventory management links across enterprise's all the operation. With the deepening of the market economy, the scale of business gradually expanding and the development of modern enterprise management, the issue of a company's inventory management is gradually highlighted day by day. Adequate supply of materials must be ensured for ship building and inventory status determines the entire production correctly in the shipbuilding enterprises, so inventory management is actually important. And for shipbuilding Enterprise inventory correctly decides the production, the shipbuilders have tried a long time, but have not yet formed a complete system of inventory management and a unified inventory evaluation index body. Inventory management is particularly important, therefore it is urgent to build a scientific and effective evaluation index system of inventory management.

Recently, numbers of scholars have carried out related research on evaluating inventory management problem. Erik Svensson (2012)conducts an inventory of environmental initiatives applicable for communicating environmental performance of ships and ship owners, and evaluate three indices based on principal aspects and criteria found in literature. The three evaluated indices were the Energy Efficiency Operational Indicator, the Performance Metrics Tool and the Clean Shipping Index [2]. Shen (2013) evaluates an empirical investigation of VMI practices in Indian SMEs. Then he presents that, the major influencing variables are improved efficiency and improved channel relations in terms of benefit [3]. Mosè Gallo (2010) presents some models considered some indexes like inventory cost and service level to assess multi-echelon inventory performance in his paper [4]. Yi Li (2010) establishes an evaluation index system of grains inventory which include 1 first-class index, 4 second-class indexes and 16 three-class indexes within supply chain environment [5]. Erhun Özkan(2013)develops a new evaluation method that provides accurate approximations for the key performance measures like fractions of 
demands supplied by the local warehouses or emergency shipments [6]. Andreas M. Radke (2013) presents an evaluation of inventory allocations along the risks of production schedule and stock out allowing identification of critical items to mitigate delays [7]. HUO Dong-fang (2010) constructs the evaluation index systems to choose vendor managed inventory by analyzing the major principles of vendor managed inventory evaluation [8]. Xianwu Hu (2013) provides an evaluation index system based on AHP and then use it to decide the weight of each evaluation index [9]. Chen Zhizong (2013) establishes a method dependent on super efficiency DEA model [10] . Above all, scholars in related fields are using a single method to complete such evaluating inventory management system studies. However, the results have been lacking for ship specializes in Enterprise inventory management. So this paper will carry out on the two aspects: (1) determine the shipbuilding industry inventory evaluation systems, (2) improve the evaluation method of the shipbuilder industry inventory.

\section{Establishment of Evaluation Index System}

Based on the related research findings, we summarize and filter the main evaluation indicators with combination the results of magnanimous field trips and visits in ship enterprises [11]. And then we modify and construct shipbuilding industry inventory evaluation system which adapts to shipbuilder industry. The following five first class indices were evaluated:

(1) Income indexes includes total investment, cost of holding inventory, utilization of materials and losses caused by corrosion warranty could reflect of the influence interests of the inventory management of entire firm.

(2) Operation indexes include the procurement of goods qualified rate, rate of timely arrival of materials, the efficiency of logistics, inventory turnover ratio and inventory accuracy could test the degree of enterprise production from different levels.

(3) Supply chain indexes consist of node affinity, the speed of information processing; supply chain systems information update rate and accuracy of information comprehensive scientific present the operation level in supply chain.

(4) Security indexes: strength of security monitoring and safe investment reflect the enterprise's strength of safe from the characteristics of ship enterprises; the material cost of maintenance and system maintenance present the investment on corporate growth.

(5) Development indexes include impact on corporate profits, response to national policy level and employee knowledge constitution reflects the business to the company's long-term development considerations from a different point of view.

The indicators are shown in the Table 1.

\section{Selecting Evaluation Methods}

The method which uses G1, G2, entropy methods and dispersion index weighting method is presented by Chi Guotai to evaluate index [12]. Based on Guotai's study, we modify and put forward a new approach which fits shipbuilder industry to evaluate the inventory evaluation model consist of G1, fuzzy Borda number analytical method, entropy value method and deviation to obtain the inventory evaluation scores. G1 and fuzzy Borda number are common in charge of evaluation index weighting method, entropy value method and deviation can scientifically weighting of indicators from objective angle. The calculation process of G1 and deviation meet the characteristics of the index number of shipbuilding enterprises in strict accuracy and data dispersion caused by the production orders [13]. These four methods respectively from two angles to each index weight determining, if the use of a single method that the results would be not comprehensive enough .Therefore 
in this paper, the four methods are used in combination so that the results are more scientific and reasonable results. Evaluate accuracy from subjective and objective aspects could be reflected by optimal combination determining weights method.

Table 1. Ship Industry Inventory Evaluation Index System

\begin{tabular}{|c|c|c|}
\hline first class & second class index & index explanation \\
\hline \multirow{4}{*}{$\begin{array}{l}\text { Income } \\
\text { indexes }\end{array}$} & Total investment & $\begin{array}{l}\text { the company's total investment on inventory } \\
\text { over a period of time }\end{array}$ \\
\hline & Cost of holding inventory & the value of the company's holding inventory \\
\hline & Utilization of materials & $\begin{array}{l}\text { whether the enterprises make full use of steel } \\
\text { plate }\end{array}$ \\
\hline & $\begin{array}{l}\text { Losses caused by } \\
\text { corrosion warranty }\end{array}$ & $\begin{array}{l}\text { the losses due to expired shelf-life and corrosion } \\
\text { damage }\end{array}$ \\
\hline \multirow{5}{*}{$\begin{array}{l}\text { Operation } \\
\text { indexes }\end{array}$} & $\begin{array}{l}\text { The procurement of goods } \\
\text { qualified rate }\end{array}$ & levels of purchasing goods related to inventory \\
\hline & $\begin{array}{c}\text { Rate of timely arrival of } \\
\text { materials }\end{array}$ & $\begin{array}{l}\text { the purchase of goods and materials is or not } \\
\text { timely delivery }\end{array}$ \\
\hline & The efficiency of logistics & $\begin{array}{l}\text { includes road conditions, quality of the logistics } \\
\text { company }\end{array}$ \\
\hline & Inventory turnover ratio & if there is enough space for new items \\
\hline & Inventory accuracy & $\begin{array}{l}\text { inventory record is or not consistent with the } \\
\text { actual }\end{array}$ \\
\hline \multirow{4}{*}{$\begin{array}{l}\text { Supply chain } \\
\text { indexes }\end{array}$} & Node affinity & $\begin{array}{l}\text { if there are gaps between each nodes and the size } \\
\text { of the gaps }\end{array}$ \\
\hline & $\begin{array}{l}\text { The speed of information } \\
\text { processing }\end{array}$ & $\begin{array}{l}\text { whether the data in the supply chain can be } \\
\text { timely treated }\end{array}$ \\
\hline & $\begin{array}{l}\text { Supply chain systems } \\
\text { information update rate }\end{array}$ & $\begin{array}{l}\text { updates at every point in the supply chain can or } \\
\text { not be reflected quickly in the system }\end{array}$ \\
\hline & Accuracy of information & $\begin{array}{l}\text { information of every node is or not consistent } \\
\text { with reality }\end{array}$ \\
\hline \multirow{3}{*}{$\begin{array}{l}\text { Development } \\
\text { indexes }\end{array}$} & $\begin{array}{c}\text { Impact on corporate } \\
\text { profits }\end{array}$ & $\begin{array}{l}\text { inventory levels impact directly or indirectly on } \\
\text { the company's profits }\end{array}$ \\
\hline & $\begin{array}{l}\text { Response to national } \\
\text { policy level }\end{array}$ & $\begin{array}{l}\text { whether the firm's decision response to the } \\
\text { national policy }\end{array}$ \\
\hline & $\begin{array}{l}\text { Employee knowledge } \\
\text { constitution }\end{array}$ & $\begin{array}{l}\text { whether the enterprise has abundant types of } \\
\text { employees }\end{array}$ \\
\hline \multirow{4}{*}{$\begin{array}{l}\text { Security } \\
\text { indexes }\end{array}$} & $\begin{array}{l}\text { Strength of security } \\
\text { monitoring }\end{array}$ & the degree of safety monitoring in the plant area \\
\hline & Safe investment & investment in security issues \\
\hline & $\begin{array}{c}\text { The material cost of } \\
\text { maintenance }\end{array}$ & the investment on extending the fixed asset's life \\
\hline & System maintenance & the investment on the system's well working \\
\hline
\end{tabular}

\subsection{The Weight Determined by G1 Method}

(1) We use G1 method to determine the order of evaluation index.

(2) Experts give the rational assignment value $r_{k}$ of the importance of adjacent indicators $x_{k-1}$ and $x_{k}$,

(3) If experts or decision-makers confirm the rational assignment value, then the G1 weight of the $\mathrm{m}$ index $w_{m}$ could be gained by formula 1 . 


$$
w_{m}=\left(1+\sum_{k=2}^{m} \prod r_{k}\right)^{-1}
$$

(4) Based on the weight $w_{m}$ we could obtain the weights of other indicators by the formula 2 .

$$
w_{k-1}=r_{k} w_{k},(k=m, m-1,1 \cdot) \cdot
$$

\subsection{The Weight Determined by Fuzzy Borda Number Analytical Method}

(1) Establish the hierarchical structure;

(2) Then establish the grid by judging the attribute;

(3) Based on the grid analysis we could get the relative weight of the single criterion.

(1) We determine the degree of membership $U_{m p}$ by formula 3 .

$$
U_{m p}=\frac{B_{m}\left(D_{p}\right)}{\max \left\{B_{m}\left(D_{p}\right)\right\}} \quad\left(0 \leq U_{m p} \leq 1\right)
$$

(2) Then make the fuzzy frequency statistics by formula 4 and $5 . f_{h p}$ is the fuzzy frequency of $D_{p} ; R_{p}$ is the sum of $D_{p}$ 's fuzzy frequency; $\delta_{m}^{h}\left(D_{p}\right)$ is the order coefficient of relationship.

$$
\begin{gathered}
f_{h p}=\sum_{m=1}^{M} \delta_{m}^{h}\left(D_{p}\right) U_{m p} \\
R_{p}=\sum_{h} f_{h p}
\end{gathered}
$$

(3) Calculate the fuzzy Borda number by formula 6 with

$$
\begin{aligned}
Q_{h}=1 / 2(N-h)(N-h+1), W_{h p} & =\frac{f_{h p}}{R_{p}} . \\
F B\left(D_{p}\right) & =\sum_{h} \frac{f_{h p}}{R_{p}} \cdot Q_{h}=\sum_{h} W_{h p} Q_{h}
\end{aligned}
$$

(4)We will get the relative weight of the single criterion with the normalized processing by formula 7 .

$$
W_{p}=\frac{F B\left(D_{p}\right)}{\sum_{p=1}^{N} F B\left(D_{p}\right)}
$$

(4) Calculate the combined weights of every index by formula $8 . W_{i j}$ is the combined weight of the third class index; $W_{i}$ is the weight of the second class index; $W_{i j}$ is the relative weight of the third class index.

$$
W_{i j}=W_{i} \cdot W_{i j}^{\prime} \quad(i=1,2 ; j=1,2,3,4)
$$

\subsection{Determine the Weight by Principle of Entropy Weight}

Entropy is a measure of uncertainty. The greater the amount of information, the less uncertainty is, the smaller entropy will be; the smaller the amount of information the greater the uncertainty is, the greater the entropy will be. Based on the principle we could get the weight by formula 9 . 


$$
w_{k}=\frac{1-e_{j}}{n-\sum_{i=1}^{n} e_{i}}=\frac{1+\frac{1}{\ln (n)} \times \sum_{i=1}^{n}\left[x_{i k} / \sum_{i=1}^{n} x_{i k}\right] \times\left[\ln \left(x_{i k} / \sum_{i=1}^{n} x_{i k}\right]\right.}{\sum_{k=1}^{m}\left\{1+\frac{1}{\ln (n)} \times \sum_{i=1}^{n}\left[x_{i k} / \sum_{i=1}^{n} x_{i k}\right] \times\left[\ln \left(x_{i k} / \sum_{i=1}^{n} x_{i k}\right]\right\}\right.}
$$

$f_{i j}=x_{i j} / \sum_{i=1}^{n} x_{i j}$ is $\mathrm{j}$ share of feature in the system index, $x_{i j}$ is $\mathrm{J}$ index data in the system, $\sum_{i=1}^{n} x_{i j}$ is $\mathrm{j}$ index sum of all the observations of the system.

\subsection{Determine the Weight with the Maximizing Deviation Method:}

The principle of the maximizing deviation method: Considered from the evaluation of the results of the impact angle, deviation degree evaluation object index value is bigger; the weight indicator should be given more. According to the principle, we structure the optimization model:

$$
\max F(w)=\sum_{i=1}^{m} \sum_{j=1}^{n} \sum_{k=1}^{n}\left|p_{i j}-p_{i k}\right| w_{i} \quad \text { s.t. }\left\{\begin{array}{l}
w_{i} \geq 0 \\
\sum_{i=1}^{m} w_{i}^{2}=1
\end{array}\right.
$$

Solving this optimization model obtain the weight $w_{k}$ by using the deviation method as formula 9

$$
w_{i}=\frac{\sum_{j=1}^{n} \sum_{k=1}^{n}\left|p_{i j}-p_{i k}\right|}{\sum_{i=1}^{m} \sum_{j=1}^{n} \sum_{k=1}^{n}\left|p_{i j}-p_{i k}\right|}
$$

Determine the combination weight by using four methods as G1, fuzzy Borda number analytical method, entropy value method and the maximizing deviation method with formula 11:

$$
w=\sum_{k=1}^{l} x_{k} W^{k}
$$

$x_{k}$ means combination coefficient decided by formula 12

$$
x_{k}=\frac{\exp \left\{-\left[1+\mu \sum_{i=1}^{n} \sum_{j=1}^{m} w_{j}^{k}\left(1-z_{i j}\right) /(1-\mu)\right]\right\}}{\sum_{k=1}^{l} \exp \left\{-\left[1+\mu \sum_{i=1}^{n} \sum_{j=1}^{m} w_{j}^{k}\left(1-z_{i j}\right) /(1-\mu)\right]\right\}}
$$

\section{Data Analysis}

\subsection{Date Calculation}

We invited 20 experts including 9 executives in ship industry, 7 scholars in researching supply chain of manufacturing enterprises and 4 competent of inventory department for marking each index score. Then based on the scoring results we gain the calculation results of each single method and combination weighting method through the methods described above. It is obvious that the weight results calculated by combination weighting method is between the minimum value and the maximum value gained through single evaluation method, is a set of reasonable steady 
numerical which integrated radical views and conservative views. The results are shown in Table 2.

Table 2. Weights and Combined Weights of Standard Data

\begin{tabular}{|c|c|c|c|c|c|c|c|}
\hline number & $\begin{array}{c}\text { first class } \\
\text { index }\end{array}$ & $\begin{array}{l}\text { second class } \\
\text { index }\end{array}$ & G1 & $\begin{array}{l}\text { fuzzy } \\
\text { number }\end{array}$ & entropy & deviate & $\begin{array}{c}\text { Combin } \\
\text { ed } \\
\text { weight }\end{array}$ \\
\hline 1 & \multirow{4}{*}{ I } & $\mathrm{I}_{1}$ & 0.083 & 0.074 & 0.071 & 0.077 & 0.076 \\
\hline 2 & & $\mathrm{I}_{2}$ & 0.069 & 0.079 & 0.080 & 0.076 & 0.077 \\
\hline 3 & & $\mathrm{I}_{3}$ & 0.065 & 0.072 & 0.083 & 0.082 & 0.080 \\
\hline 4 & & $\mathrm{I}_{4}$ & 0.050 & 0.053 & 0.079 & 0.069 & 0.065 \\
\hline 5 & \multirow{5}{*}{$\mathrm{O}$} & $\mathrm{O}_{1}$ & 0.054 & 0.067 & 0.082 & 0.080 & 0.078 \\
\hline 6 & & $\mathrm{O}_{2}$ & 0.058 & 0.054 & 0.070 & 0.069 & 0.066 \\
\hline 7 & & $\mathrm{O}_{3}$ & 0.069 & 0.061 & 0.078 & 0.075 & 0.071 \\
\hline 8 & & $\mathrm{O}_{4}$ & 0.065 & 0.059 & 0.072 & 0.070 & 0.068 \\
\hline 9 & & $\mathrm{O}_{5}$ & 0.069 & 0.074 & 0.085 & 0.073 & 0.079 \\
\hline 10 & \multirow{4}{*}{$\mathrm{C}$} & $\mathrm{C}_{1}$ & 0.062 & 0.059 & 0.079 & 0.071 & 0.073 \\
\hline 11 & & $\mathrm{C}_{2}$ & 0.053 & 0.052 & 0.067 & 0.064 & 0.052 \\
\hline 12 & & $\mathrm{C}_{3}$ & 0.051 & 0.053 & 0.071 & 0.067 & 0.065 \\
\hline 13 & & $\mathrm{C}_{4}$ & 0.066 & 0.073 & 0.079 & 0.076 & 0.074 \\
\hline 14 & \multirow{3}{*}{ D } & $\mathrm{D}_{1}$ & 0.068 & 0.065 & 0.084 & 0.072 & 0.075 \\
\hline 15 & & $\mathrm{D}_{2}$ & 0.057 & 0.066 & 0.076 & 0.078 & 0.071 \\
\hline 16 & & $\mathrm{D}_{3}$ & 0.053 & 0.064 & 0.078 & 0.071 & 0.068 \\
\hline 17 & \multirow{4}{*}{$S$} & $S_{1}$ & 0.081 & 0.082 & 0.092 & 0.090 & 0.085 \\
\hline 18 & & $\mathrm{~S}_{2}$ & 0.068 & 0.079 & 0.093 & 0.089 & 0.082 \\
\hline 19 & & $\mathrm{~S}_{3}$ & 0.060 & 0.067 & 0.080 & 0.075 & 0.070 \\
\hline 20 & & $\mathrm{~S}_{4}$ & 0.050 & 0.057 & 0.073 & 0.069 & 0.064 \\
\hline
\end{tabular}

Based on the results calculated from the Table above we could conclude that income indicators, operation indicators and security indicators are the three most important indices for evaluating the level of shipbuilding enterprise inventory management. These coincide with shipping enterprises ' features which consider safety first, in order to production-oriented. In a company, income issue is a top priority which decides whether to continue operating and development, managers at any level in organization should take into account the overall cost of profits and benefits. So income evaluation indicators are the most significant indicators in the evaluation system. During the entire shipbuilding process, deliver on time is a manifestation of shipbuilding enterprise credit and flow of the process is the guarantee to the enterprises normal production, so operation indicators are the major embodiment of the inventory management level. Meanwhile, inventory security issues are also important ones which need more attention of shipbuilding enterprises. So no matter what kinds of materials in warehouses, safe investments and monitors will be highly valued by each employee and manager.

\subsection{Empirical Analysis}

In order to verify the evaluation indicator system and weighting the results whether are consistent with the actual situation of shipbuilding enterprise or not, we choose a mature shipbuilder--LFS to complete the empirical studies. LFS is a leading company in the shipbuilding industry with decades of experience in 
shipbuilding, its inventory management level has been tending stable and mature with years of development experience. As its inventory management level in the industry is in a leading position, so we select LFS that is a good typical to be the object of study. Shipbuilders of inventory is generally divided into eight categories: piping accessories--PA, sheet plate (Outfitting, Steel Outfitting equipment) --SP, electrical accessories (Auxiliary Malts) --EA, pipes--P1, cables--CI, accessories(Tooling/Sling)--AI, profiles(Drilling equipments) - $\mathrm{P} 2$, as well as the other-OI. The initial data is provided by the business sector, considering the requirement of confidentiality and the lack of space, we only provide calculated results, which is shown in Table 3.

Table 3. Grades and Rank for Eight Categories of Materials

\begin{tabular}{|c|c|c|c|c|c|c|c|c|c|c|}
\hline \multirow[t]{2}{*}{ No. } & \multirow{2}{*}{\multicolumn{2}{|c|}{ score }} & \multicolumn{8}{|c|}{ grades and rank } \\
\hline & & & PA & SP & EA & P1 & $\mathrm{CI}$ & $\mathrm{AI}$ & $\mathrm{P} 2$ & $\mathrm{OI}$ \\
\hline \multirow{2}{*}{1} & \multirow{2}{*}{$\begin{array}{l}\text { tota } \\
1\end{array}$} & score & 0.781 & 0.803 & 0.766 & 0.795 & 0.618 & 0.592 & 0.486 & 0.690 \\
\hline & & rank & 3 & 1 & 4 & 2 & 6 & 7 & 8 & 5 \\
\hline \multirow{2}{*}{2} & \multirow{2}{*}{ I } & score & 0.062 & 0.075 & 0.053 & 0.071 & 0.044 & 0.053 & 0.038 & 0.069 \\
\hline & & rank & 4 & 1 & 5 & 2 & 7 & 5 & 8 & 3 \\
\hline \multirow{2}{*}{3} & \multirow{2}{*}{$\mathrm{O}$} & score & 0.064 & 0.085 & 0.080 & 0.076 & 0.058 & 0.055 & 0.053 & 0.061 \\
\hline & & rank & 4 & 1 & 2 & 3 & 6 & 7 & 8 & 5 \\
\hline \multirow{2}{*}{4} & \multirow{2}{*}{$\mathrm{C}$} & score & 0.132 & 0.139 & 0.126 & 0.154 & 0.094 & 0.100 & 0.112 & 0.150 \\
\hline & & rank & 4 & 3 & 5 & 1 & 8 & 7 & 6 & 2 \\
\hline \multirow{2}{*}{5} & \multirow{2}{*}{$\mathrm{D}$} & score & 0.079 & 0.081 & 0.068 & 0.079 & 0.082 & 0.057 & 0.061 & 0.058 \\
\hline & & rank & 3 & 2 & 5 & 3 & 1 & 8 & 6 & 7 \\
\hline \multirow{2}{*}{6} & \multirow{2}{*}{$\mathrm{S}$} & score & 0.140 & 0.132 & 0.107 & 0.123 & 0.086 & 0.058 & 0.077 & 0.079 \\
\hline & & rank & 1 & 2 & 4 & 3 & 5 & 7 & 8 & 6 \\
\hline
\end{tabular}

From the data in the Table we can obtain that among all kinds of materials inventory management evaluation, ranking in the top three items are sheet plate, piping accessories and pipes. During the ship construction process, these three categories of materials are necessary basic materials. Shipbuilders have high purchasing frequency, large quantity of demand and strict delivery timeliness requirements at the three types of material. Therefore, these supplies stock management levels could reflect the overall quality and level of inventory management in shipyards to some extent. Meanwhile, the sub-index of three types of material inventory management also ranked at front, this result reflects the efficiency of inventory management of these three types basic material in LFS, also confirmed that as an leading enterprise in shipbuilding industry LFS has strong strength and high levels on inventory management. Table 3 shows that the score of inventory management evaluation at behind three such as profiles, accessories, cables. Particularly the latter two categories have a large gap compared with other materials, which means that samples enterprise LFS are not perfect in inventory management, there are still some areas requiring improvement and perfection. The reason lies in these three categories of goods are auxiliary materials in ship manufacturing processes, their cost are lower, share of shipbuilding costs are smaller, so they get not enough sufficient attention on inventory management.

\section{Conclusion}

Evaluation index system in this article is closely integrated shipbuilding enterprise features, building up with comprehensively considering the ship's cost 
structure, production stage, supplies process and other aspects. It could fully reflect the efficiency, security, development and the other aspects of the important regulatory requirements in shipping enterprise. In order to make the evaluation results of the index system more effective we adopt combination weighting method which synthesizes all kinds of subjective and objective weighting method to determine the weight of each indicator. Empirical results show that this method could effectively avoid the phenomenon of using the individual method of empowering approach makes some indicators arise too high or too low.

The empowering results of shipbuilding enterprise show that income index, operation index and security index is the three top important indicators to evaluate the ship inventory management level. In order to improve the income index, shipping enterprises could establish different benefit contest mechanism between the distinct warehouses, which includes regular study, comparative analysis of warehouse inventory backlog cost ratios, utilization of materials, supplies corrosion loss rate, and other indicators, using reward form for superior and punishment for perpetrators to improve overall stock gains. In order to improve operation indicators, enterprises should start with procurement procedures through establishment of supplier evaluation and elimination mechanism for selecting quality suppliers to ensure materials pass rate and timely arrival rate. At the same time the enterprise could strengthen inventory accuracy and inventory turnover by business training to improve staff skills and management level of inventory. For optimal security indicators, shipping enterprises should increase investment in safety measures, such as the procurement of security equipment, installing security monitoring devices, enhanced employee training on inventory system maintenance and operation to improve the quality of inventory, inventory system run levels, in order to achieve safe and efficient protection for ship production inventory management functions.

Based on the inventory management evaluation of the eight categories goods in the sample enterprises, the paper makes the following suggestions: 1) For the most critical supplies sheet metal, the sample enterprise should continue to maintain the overall advantage in this kind of material inventory management. But the supply chain indicators ranking only at the third position, which reflected out that LFS has insufficient in supply chain management on the aspect of steel plate. The enterprise could strengthened its attention degree on supply chain management system through training related inventory management personnel, so as to achieve that ensure the rational allocation of steel plate material at the same time promote the supply chain management level 2) The pipe is also an important material for shipbuilding enterprises just behind the steel plate, the total score ranking and sub index rankings of this kind of material inventory management in the sample enterprises are relatively in front places. The enterprises should continue to maintain the high level of management at the same time constantly sum up the successful experience of the material management in order to popularize and promote 3) For piping accessories, sample enterprises should properly set aside material reserves of pipe accessory to prepare for possible period of want or need. Meanwhile the enterprise should construct scientific supplier evaluation system through combining with the purchasing department to evaluate and select quality suppliers, strive to maintain its long-term cooperation relationship, which can not only to ensure the production process smooth, also could maintain the stability of the supply chain. 4) For ranking of inventory management evaluation at the last three materials profiles, accessories and cables, the enterprise should attach importance to them by scientific management. Considering these three kinds of materials occupied less cost and space, we suggest that the shipbuilding enterprises could handle these three categories of materials for unified management, which may save space and reduce 
human resource consumption. Moreover the enterprise could use the theory of $\mathrm{ABC}$ classification management method, go a step further refine the inventory management of auxiliary materials to improve the quality of these kinds of material inventory management.

\section{Acknowledgement}

The report is supported by project on information management system of jack-up drilling platform and Natural Science Foundation of China (71173059,71372020), Specialized Research Fund for the Doctoral Program of Higher Education(20132304110025).

\section{References}

[1]. D. Simchi-Levi and Y. Zhao, "Performance Evaluation of Stochastic Multi-Echelon Inventory Systems: A Survey", Advances in Operations Research, (2012), pp. 1-34.

[2]. E. S. K. Andersson, "Inventory and Evaluation of Environmental Performance Indices for Shipping", CHALMERS UNIVERSITY OF TECHNOLOGY, (2012).

[3]. G. Shen, D. Borade and Kannan, "An evaluation of vendor managed inventory practices from small and medium Indian enterprises", Journal of Business Economics and Management, vol. 14, no. 20, (2013), pp. S76-S95.

[4]. L. G. G. N. Mosè Gallo, "Multi-Echelon Inventory Performance Evaluation: The Case of a Communications Company", Business Performance Measurement and Management, Springer Berlin Heidelberg, (2010), pp. 293-310.

[5]. L. Yi, "Under the condition of supply chain evaluation index system of grains inventory", Logistics SciTech, vol. 6, no. 218, (2012), pp. 26-44.

[6]. E. Özkan, G. V. Houtum and Y. Serin, "A new approximate evaluation method for two-echelon inventory systems with emergency shipments", Annals of Operations Research, (2013).

[7]. A. M. Radke, T. Tolio, M. M. Tseng and M. Urgo, "A risk management-based evaluation of inventory allocations for make-to-order production”, CIRP Annals - Manufacturing Technology, vol. 62, (2013), pp. 459-462.

[8]. H. D. Fang and R. J. L. Qin-Zhen, "Evaluation and Analysis on Vendor Managed Inventory of War Reserve Materiel”, Logistics Sci-Tech, (2012), pp. 112-114.

[9]. X. Hu, "Based on the AHP Small and Medium-Sized Enterprise Supply Chain Vendor Evaluation Research", Research Journal of Applied Sciences, J. Engineering and Technology, vol. 22, (2013), pp. 5303-5307.

[10].C. Z. YouJianXin, "based on super efficiency DEA model Context - Dependent vendor evaluation", industrial Engineering and Management, (2013).

[11].L. Ye, Y. Chen and S. Frank, "Optimal Pricing and Inventory Control Policy with Quantity-Based Price Differentiation", Operations Research, vol. 3, no. 62, (2013), pp. $512-523$.

[12].C. G. Tai and Q. Z. Nan, "The optimal portfolio based on the urban ecological evaluation model and application of empowerment", Operations research and management science, (2012).

[13].H. Dong-Fang, R. Jie and L. Qin-Zhen, "Evaluation and Analysis on Vendor Managed Inventory of War Reserve Materiel”, Logistics Sci-Tech, vol. 2, (2010), pp. 112-114.

\section{Authors}

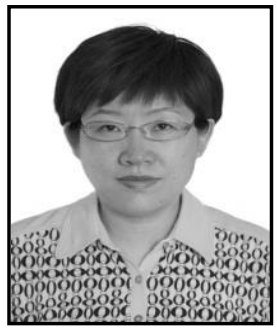

Sun Bing: (1972.3), female, the Han nationality, Prof. of diffusion of technological innovation, Doctor's degree, Doctoral tutor. 
International Journal of $u-$ and e- Service, Science and Technology

Vol.8, No.2 (2015)

Wang Hongying: (1988.7), female, the Han nationality, Prof. of diffusion of technological innovation, Graduate student. Tel: 13199543560, Email:wanghongying0723@163.com 